\title{
INTERFERON-INDUCED PARKINSONISM IN A PATIENT WITH CHRONIC HEPATITIS C
}

\author{
Carlos Mauricio Oliveira de Almeida', Maria de Lourdes de Souza Galvão?, \\ Paulo Luis da Costa Ferreira ${ }^{2}$, Wornei Silva Braga²
}

Hepatitis $C$ is considered a public health and economic problem worldwide?. An estimated 180 million people are chronically infected with the hepatitis $\mathrm{C}$ virus $(\mathrm{HCV})$, and 3 to 4 million new cases of infection occur annually? $\mathrm{HCV}$ is a single-stranded RNA virus, belonging to the Flaviviridae family and the Hepacivirus genus ${ }^{2-4}$. Six distinct genotypes and 76 subtypes have been described ${ }^{5,6}$. The current treatment for hepatitis $C$ is administration of interferon alpha (IFN- $\alpha$ ) or its most recent form, pegylated interferon (Peg-IFN), combined with ribavirin and the duration of treatment ranging from 12 to 24 weeks depending on the genotype involved'.

The use of interferon has been associated with many neuropsychiatric complications, such as fatigue, confusional state, seizures, depression and even risk of suicidal ideation ${ }^{8,9}$. In recent years, it has emerged that patients treated with IFN- $\alpha$ or Peg-IFN can present rare neurological motor complications, such as dystonia, myorhythmia, chorea and Parkinsonism syndrome $e^{9-15}$.

There have been few reported cases of Parkinsonism in hepatitis $C$ patients treated with interferon, and there is therefore a need to clarify the treatment options in such cases. Here, we describe the case of a patient who developed Parkinsonism upon being treated with Peg-IFN- $\alpha$.

\section{CASE}

A 65-year-old female patient, diagnosed 2 years prior with chronic hepatitis $\mathrm{C}$, genotype 3 , and probably infected via a blood transfusion performed 16 years earlier, presented to the Fundação de Medicina Tropical do Amazonas complaining of intense fatigue. She presented a Fatigue Severity Scale score of 4. 1 points. She was hypertensive and was under continuous treatment with propranolol. The patient had no history of neurological disease. Treatment was started with Peg-IFN- $\alpha$ 2a (180 $\mu \mathrm{g} /$ week) plus ribavirin ( $1 \mathrm{~g} /$ day). After exactly 2 months of using this medication, she presented symmetrical stiffness in the upper limbs and low-frequency tremors at rest and posture. The results of the cognitive and postural examinations, as well as the deep tendon reflexes and the cranial nerves, were normal. Nevertheless, the treatment was suspended. At approximately two months after the discontinuation of the treatment, an MRI of the brain was performed, and the results were normal. Laboratory tests to determine the levels of thyroid-stimulating hormone, tetraiodothyronine, copper and ceruloplasmin all yielded normal results, and serology for HIV was negative. However, the patient continued to present tremors and rigidity. Treatment with the levodopa-benserazide combination was started with $125 \mathrm{mg} /$ day, and the dose was gradually increased up to $250 \mathrm{mg} /$ day. Partial improvement of the tremors and upper-limb rigidity was observed. At this writing, the patient remained under treatment with levodopa.

\section{DISCUSSION}

Interferons are naturally occurring cytokines that have antiviral, immunomodulatory and antiproliferative effects ${ }^{9,12,13,16}$. The IFN-1 family consists of two distinct groups of proteins designated IFN- $\alpha$ and IFN- $\beta^{16}$. The former is used to treat various infectious diseases, such as hepatitis $C$, as well as tumors and leukemia ${ }^{7,12,13}$. The association between IFN- $\alpha$ use and Parkinsonism was first described by Mizoi et al..$^{12}$ in 1997. Subsequent reports have shown that this complication can also result from treatment with Peg-IFN'

Here, we describe the first case of Peg-IFN-induced Parkinsonism in Brazil. The patient had no history of neurological disease, and the symptoms of Parkinsonism appeared after only 8 weeks of treatment with Peg-IFN. The presentation of symmetric stiffness and tremors at rest, as well as the absence of other conditions that might explain such symptoms, led us to attribute the Parkinsonism symptoms to the use of the interferon. The patient did not meet the clinical criteria for a diagnosis of hepatic encephalopathy, nor did she present the disorientation, flapping tremors or jaundice that would characterize such a diagnosis, which was therefore excluded.

Studies in rats have shown that the continuous use of

\section{PARKINSONISMO INDUZIDO PELO USO DE INTERFERON EM PACIENTE COM HEPATITE C CRÔNICA}

Fundação de Medicina Tropical do Amazonas, Manaus AM, Brazil: 'Neurology Department; ${ }^{2}$ Hepatitis Department.

Received 6 November 2008, received in final form 24 April 2009. Accepted 13 June 2009.

Dr. Carlos Mauricio Almeida - Rua Billy Holiday 36 / 402-C - 69050-440 Manaus AM - Brasil. E-mail: acrmauri@ig.com.br 
IFN- $\alpha$ has an inhibitory effect on nigrostriatal dopaminergic transmission, suggesting a similar effect in human beings ${ }^{17}$. Studies with ribavirin have shown systemic side effects such as anemia and osteopenia but no effects on dopaminergic transmission ${ }^{18-20}$. Therefore, we also ruled out the possibility that the Parkinsonism symptoms seen in our case resulted from the use of ribavirin rather than that of interferon.

Data in the literature suggest that the average time for the appearance of Parkinsonism symptoms is variable and can be as long as 30 weeks after the initiation of therapy with interferon ${ }^{12-15}$. In all reported cases, the Parkinsonism symptoms persisted after discontinuation of interferon and there was partial improvement after treatment with levodopa, indicating a need for continued pharmacological treatment, as in our case. In a study involving 14 patients treated with interferon, Meyers et al. ${ }^{9}$ also demonstrated the persistence of some of these systemic effects.

In presenting this case, we aim to call attention to the complications of the use of interferon, especially those that involve the dopaminergic system, since little is known about such complications, which are still considered rare. Further studies involving larger patient samples or animal models are needed in order to determine the action of interferon and its potential effects on human dopaminergic neurons.

\section{REFERENCES}

1. Organização Mundial de Saúde. Hepatite C. Disponível em: < http:// www. who. int/docstore/wer/pdf/1999/ wer7449. pdf /> Acesso em: 18 setembro. 2008.

2. Choo Qui-Lim, Amy GK, Weiner AJ, Overby LC, Bradley DW, Houghton $\mathrm{M}$. Isolation of c-DNA clone derived from a blood-borne non-A, non-B viral hepatitis genome. Science 1989;244:359-361.

3. Bukh J,Purcell RH, Miller RH. Sequence analysis of the 5'noncoding region of hepatitis C virus. Proc Natl Acad Sci 1992;89:4942-4946.
4. Kato N, Hijikata M, Ootsuyama Y, et al. Molecular cloning of the human hepatitis $\mathrm{C}$ virus genome from Japanese patients with non- $\mathrm{A}$, non-B hepatitis. Proc Natl Acad Sci 1990;87:9524-9528.

5. Simmonds P, Holmes EC, Cha TA, et al. Classification of hepatitis C virus into six major genotypes and a series of subtypes by phylogenetic analysis of the NS-5 region. J Gen Virol 1993;74:. 2391-2399.

6. Simmonds P, Bukh J, Combet C, et al. A Consensus proposals for a unified system of nomenclature of hepatitis $\mathrm{C}$ virus genotypes. Hepatology 2005;42:962-973.

7. de Araújo ES, Mendonça JS, Barone AA, et al. Consensus of the Brazilian Society of Infectious Diseases on the management and treatment of hepatitis C. Braz J Infect Dis 2007;11:446-450.

8. Manns MP, Wedemeyer H, Cornberg M. Treating viral hepatitis C: efficacy, side effects, and complications. Gut 2006;55:1350-1359.

9. Meyers CA, Scheibel RS, Forman AD. Persistent neurotoxicity of systemically administered interferon-alpha. Neurology 1991:41:672-676.

10. Moulignier A, Allo S, Zittoun R, Gout O. Recombinant interferon-a-induced chorea and frontal subcortical dememntia. Neurology 2002;58: 328-330.

11. Tan Eng-King, Chan Ling-Ling, Lo Yew-Long. Myorhythmia slow facial tremor from chronic interferon alpha-2a usage. Neurology 2003:61: 1302-1303.

12. Mizoi Y, Kaneko H, Oharazawa A, Kuroiwa H. Parkinsonism in a patient receiving interferon alpha therapy for chronic hepatitis C. Rinsho Shinkeigaku 1997;37:54-56.

13. Wada Y, Kuwahara T, Uyama E, et al. Neurologic toxicity associated with interferon: a therapy for renal cell carcinoma. Internat J Urol 2006; 13:811-813.

14. Couto CM, Ribas FD, Fonseca PG, et al. Interferon-alfa como causa de parkinsonismo: relato de Caso. Arq Neuropsiquiatr 2008;66(Suppl 2): 238.

15. Bersano A, Aghemo A, Rumi MG, Ballabio E, Candelise L, Colombo M. Recovery after L-DOPA treatment in peginterferon and ribavirin induced parkinsonism. Eur J Inter Med 2008;19:370-371.

16. Abbas AK, Lichtman AH. Citocinas. In: Abbas AK, Lichtman AH (Eds). Imunologia celular e molecular. $5^{\text {a }}$ Ed. Rio de Janeiro: Elsevier, 2005: 251-282.

17. Shuto H, Kataoka Y, Horikawa T, Fujihara N, Oishi R. Repeated interferon- $\alpha$ administration inhibits dopaminergic neural activity in the mouse brain. Brain Res 1997;747:348-351.

18. Di Bisceglie AM, Shindo M, Fong TL, et al. A pilot study of ribavirin therapy for chronic hepatitis C. Hepatology 1992;16:649-654.

19. Urganci N, Gulec SG, Arapoglu M, Vural S, Nuhog A. the effect of ribavirin on bone density in patients with chronic hepatitis $C$ treated with interferon-ribavirin therapy. J Pediatr Gastroenterol Nutr 2005;41:650-652.

20. Martin P, Jensen DM. Ribavirin in the treatment of chronic hepatitis C. Hepatology 2008;23:844-855. 